\title{
JOSÉ CORREA DA SERRA E OS ÍNDIOS BRASILEIROS.
}

O abade José Francisco Correa da Serra nasceu em Serpa, Portugal, a 6 de junho de 1750 (1). Em 1756, sua família foi forçada a fugir de Portugal e passou a residir em Nápoles. O jovem Serra recebeu sua primeira educação ali, indo mais tarde para Roma, onde se especializou em botânica. Ordenado sacerdote em 1755 , recebeu o doutoramento em leis em Roma em 1777. Durante seus estudos recebeu o patrocínio de Dom João Carlos, Duque de Lafões, com quem voltou a Portugal ao fím do período pombalino. Participando da fundação da Academia Real de Ciências, veio a se tornar seu secretário permanente. Dedicando-se a estudos botânicos, também se ocupou de outros campos, começando a edição da valiosa Coleção de livros inéditos da história portuguêsa. Tendo sido obrigado exilar-se novamente, pois seu liberalismo tornara-se suspeito em Portugal, primeiramente foi para Londres e depois para Par:s. Em ambas as cidades. foi admitido nas mais altas sociedades e círculos científicos. Por fim. deixou a França pelos Estados Unidos em 1811, onde já fizera conhecimento e amizade entre os 'eruditos. Nos Estados Unidos foi logo eleito sócio da American Philosophical Society e travou intimo contacto com a elite política e cultural principalmente com o grupo de liberais conhecidos como o Jefferson Circle.

Em 1816, foi nomeado ministro plenipotenciário do Reino Unido nos Estados Unidos e neste posto permaneceu até sua partida em 1820 para Europa, tendo sido antes nomeado membro do Conselho da Fazenda em 1819. Chegou à Inglaterra durante o período instável entre os primeiros meses da Revolu-

(1). - Para a vida de Serra vide Augusto da Silva Carvalho, o abade Correia da Serra ((Lisboa, 1948). Suas atividades nos Estados Unidos em geral têm sido analisadas por Joseph Eugene Agan em "Corrêa da Serra", The Pennsylvania Magazine of History and Biography XLIX, 1 (1925), 1-43. Para sua atividade no meio intelectual norte-americano e para as suas cartas ao círculo de Jefferson, vide Richard Beale Davis, "The Abbé Correa in America, 1812-1820", Transactions of the American Philosophical Society New Series, XIV, Parte 2a. (Maio de 1955), 85-197. 
ção de 1820 e o regresso de Dom João VI para Lisboa em 1821. Permaneceu no norte da Europa até voltar para Lisboa um pouco depois da chegada de Dom João. Participando do govêrno, foi eleito deputado de Beja às Côrtes Gerais Ordinárias de 1822-1823. Morreu em Caldas da Rainha a 11 de setembro de 1826.

Enquanto permaneceu no Nôvo Mundo, estava ocasionalmente interessado no Brasil. Como ministro português, estava oficialmente preocupado com os corsários americanos que ajudavam José Artigas no Uruguai e com a simpatia popular norte-americana em relação à Revolução Pernambucana de 1817. Infelizmente nas cartas particulares a seus amigos nos Estados Unidos, não há muitas referências ao Brasil. Há uma, porém, que espanta. Em novembro de 1820, escrevendo a Francis Walker Gilmer (2), quando estava de partida para a Europa, afirma:

Ufane-se o senhor por ser de Virginia e se lembre de todos os meus conselhos sôbre a Virgínia. Seria o destino que eu teria desejado para mim se eu fôsse norte-americano, [sic] sendo sul-americano estou contente por ser brasileiro e o senhor ouvirá do que farei por meu pais se viver (3).

Por certo esta afirmação mostra que da parte dêste liberal português não havia distinções entre o Nôvo e o Velho Mundo. Nem tão pouco seus amigos norte-americanos parecem ter distinguido Brasil e Portugal, ou se tivesem, considerariam Correa como um cidadão do Nôvo Mundo. Assim Jefferson em carta de despedida a Correa escreve:

... o amor ao seu país será um incitamento à promoção daquela intima harmonia entre nossas duas nações, o que é de tanto interêsse das duas. Nada é tão importante quanto a América separar-se dos sistemas da Europa e estabelecer um seu próprio. Nossas circunstâncias, nossos fins, nossos interêsses são distintos. Os princípios de

(2). - Gllmer (1790-1826) estudou na faculdade de Georgetown em Washington, D. C. e William and Mary em Williamsburg, Virginia; era advogado, escritor e professor. Amigo dos mais importantes intelectuais norteamericanos, que o consideravam de grande futuro. Infelizmente, por sua fraca saúde, morreu cêdo. Vide Dictionary of American Biography, VII, 306.

(3). - Correa to Gilmer, Nova York, 9 de novembro de 1820, impresso em Davis, loc. cit., 182-183. O original está na Universidade de Virginia. "Glory yourself in being a Virginian, and remember all my discourses about $\mathrm{Va}$. It is the lot $i$ would have wished for me if $i$ was a North American. being a South American I am glad to be a Brazilian, and you shall hear of what i do for my country if i live". 
nossa política também devem ser assim. Todos os envolvimentos com aquela quarta parte do globo deveriam ser evitados se intencionar-mos que a paz e a justiça sejam as estrelas guias das sociedades americanas (4).

Continuando, Jefferson escreve que mandara uma carta a um amigo na qual afirma que Correa promoveria a amizade entre as nações americanas e que êle, Jefferson, esperava ver as frotas do Brasil e dos Estados Unidos juntas no pôrto como irmãs da mesma família (5).

O tratado de Correa sôbre a situação dos índios brasileiros parece ter sido escrito para informar Jefferson. Infelizmente não é datado. Com outra mão aparece no alto da primeira página a data de 6 de março de 1812, mas isto parece muito improvável, pois naquela data Correa ainda não era tão ligado a Jefferson. O Professor Richard Beale Davis, editor crítico das cartas de Correa ao Círculo de Jefferson, acha que êste tratado foi escrito em 1815, depois de uma visita de Correa aos índios cherokee (6).

O ensaio, como se verá, é um tratado geral; não só, como - Professor Davis nota, uma descrição dos índios do Brasil, mas também um esquema para uso dos norte-americanos daquilo que fôra feito para os indígenas brasileiros com a sugestão implícita de que tais medidas poderiam ser seguidas.

$O$ ensaio demonstra algum conhecimento sôbre os índios, todo êle evidentemente extraído de fontes secundárias. $O$ trabalho não é, de modo algum, influenciado pelas teorias do beau sauvage dos pensadores europeus da sua geração, nem tão pouco cai no extremo oposto do pensamento colonial contemporâneo. Não é em nada pretencioso em sua simplicidade e a única referência a um trabalho anterior mostra que Correa da Serra, que era extraordinàriamente instruido, não dedicara muita atenção ao assunto. Seu resumido esfôrço não pode ser comparado, é claro, com o trabalho do seu jovem colega da Acadê-

(4). - Thomas Jefferson to Correa, Monticello, Virgínia, 24 de outubro [1820] impresso em Davis, loc. cit., 181-182. o original está na Seção dos manuscritos, Biblioteca do Congresso, Washington, D. C. ... "the love of your own country will be an incitement to promote that intimate harmony between our two nations which is so much the interest of both. nothing is so important as that America shall separate herself from the systems of Europe, establish one of her own. our circumstances, our pursuits, our interests are distinct. the principles of our policy should be so also. all entanglements with that quarter of the globe should be avoided if we mean that peace anjustice shall be the polar stars of the american societies".

(5). - Davis loc. cit., pp. 181-182, nota 379.

(6). - Davis, loc. cit., p. 117. 
mia Real das Ciências, José Bonifácio de Andrada e Silva cujos Apontamentos mostram mais cuidado e reflexão e cuja finalidade era evidentemente muito mais ambiciosa (7).

Correa da Serra tanto elogia como condena as práticas lusobrasileiras anteriores. Por outro lado, as práticas norte-americanas da época são elogiades. Isto não pode ser considerado ùnicamente como lisonja para seus anfitriões. A opinião de Correa sôbre as medidas governamentais e particulares nos Estados Unidos em relação aos índios não era única. Assim pensavam brasileiros ligados ao problema. Em seus Apontamentos, José Bonifácio sugeriu a imitação da prát:ca dos Estados Unidos em comprár as terras dos índios (8). Francisco Moniz Tavares, cronista da Revolução Pernambucana de 1817 e deputado às Côrtes Gerais de 1821-1822, recomendou as práticas norteamericanas em sua proposta para a resolução do problmea índ'o que submetera às Côrtes (9). E o grande jornalista brasileiro, Hipólito da Costa, também endossou as técnicas norteamericanas (10). Porém, devemos nos lembrar de que Correa da Serra e seus contemporâneos brasileiros estavam escrevendo no início do século XIX, antes de que a grande destruição das nações índias no oeste norte-americano tivesse começado.

O documento foi escrito de próprio punho por Correa, em três páginas. No alto da primeira página, como dissemos acima, estão as palavras [Mar[ch] 6. 1812]. No fim do documento do próprio punho de Thomas Jefferson estão escritas as palavras Indians of Brazil Correa. O documento está arquivado na Seção de Manuscritos da Biblioteca do Congresso em Washington, D.C. e classifica-se nos Papéis de Thomas Jefferson, número 34720-1. É escrito em inglês claro, ainda que às vêzes estranho. As regras de pontuação, de ortografia e de letras maiúsculas nem sempre são respeitadas, mas isto era comum na América do Norte no comêço do século XIX.

(7). - Georze C. A. Boehrer, Apontamentos para a civilização dos indios bárbaros do reino do Brasil por José Bonifácio de Andrada e sllva, edição crítica. (Lisboa, 1963).

(8). - Ibid., 62 .

(9). - Francisco Moniz Tavares n'o Correio do Porto, 18 de maio de 1822.

(10). - Vide Correio Brasiliense, XVI, 84-88. Para um resumo da política dos Estados Unidos em relação à compra das terras dos indios, vide Alice $C$. Fletcher, "Land Tenure" in Frederick W. Hodge (Ed.), Handbook of American Indians North of Mexico (Washington, 1907), Parte 1a., 756-757. 


\section{O TEXTO}

[34720r]

$[$ Mar 6,1812$]$

The case of the Brazilian Indians

During more than two centuries the Missionaries had worked with much zeal in what is called the reduction of. Indians, that is to say, in fixing them in particular spots, christianizing them and brin-. ging them to the allegiance of Portugal by pacific means.

The nations with whom was any occasion of war, were almost always subdued, and the prisoners either reduced to a bondage like the Spanish Encomien[da]s, or to personal slavery if the war had been caried [on] by [vol] unteer forces, and not at the expense of the crown.

The first class above mentioned was in fact a church property though not in positive slavery. They were much happier than the Spanish Indians and more advanced, according to La Condamine who had visited both (11). Here as anywhere else the church has been the best civilizer of barbarians, though they are civilized for her profit.

The second class was in nearly the same inconvenient state of the Spanish Encomiendas.

In the year 1753 [sic] King Joseph declared all his Indian subjects intirely [sic] free, and enjoying the same liberties, [as] his white $[34720 \mathrm{v}]$ subjects and assimilating them in every respect. He kept a strong hand in the execution of the Law, and public opinion helped him. They are now perfect masters of their persons and property and obliged to no particular service, nor is there any, the least discrimination between them and the whites.

This plenitude of Liberty and the facility of subsistence, has sensibly increased their habits of indolence and aversion to Labour to which nobody can oblige them.

Their population is rather advancing; they are scattered in numberless villages throughout all the kingdom, mixed with the whites or by themselves. Where they are mixed, the local magistrates are of both races, where they are alone, the magistrates are chosen among themselves. They are all Christians, and generally speak Portuguese. Their number is little short of a million (12).

What would be the properest means to convert them to Labour and industry? They are at present useless members of the nation. Blacksmiths and Looms have been of late introduced among them

(11). - Vide Charles Marie da La Condamine, Relation abrégée d'un voyage fait dans l'intérieur de l'Amérique méridionale depuis la Côte de La Mer du Sud, Jusqu'aux Côtes đu Brésil e de la Guyana, en descendant la Rivière des Amazonas. (Maastricht, 1887), 86 et seq.

(12). - Ángel Rosenblat $\mathrm{cm}$ seu La población indigcna y el mestizaje en América (Buenos Aires, 1954), I, 36-37, tábula, dá o número de 360.000. 
according to the plan you put in practise here (13), but it is remarked in this beginning, that when they have got what they want no human power can persuade them to labour farther.

[3472lr]

Te Indian nations that still exist and are pretty numerous, we do not treat as you treat yours, because we do no buy the lands in which they live, and indeed they have no idea of the property of land. When we are at peace, Merchants and Missionaries persuade them to come and settle with our Indians, and no superior difficulty is found in that, particularly when they are pressed by powerful enemies, because when they come to the King's allegiance, they are powerfully protected from their enemis, and continue to enjoy full liberty. When we are at war, the warriors only are killed, and perhaps with too little humanity, but the children and women are sought with great diligence, and by all sorts of strategems, and brought to the old indian[sic] villages at a distance from their nation, in order to increase the population.

You see from this short exposition that your task was more difficult from ours. You attempted to civilize independent barbarians, a task which we do not pretend to undertake; nor do we feel the necessity of it. What we want to know is the best means of bringing to complete civilization, dependent though free barbarians. The freedom they enjoy is perhaps the greatest obstacle, but there is not the least wish of curtailing it. Our wish is to move them to be in fact, what they are by Law, a real augmentation of the class of white subjects.

\section{Indians of Brazil Correa.}

\section{GEORGE C. A. BOEHRER}

Departamento de História, Universidade de Kansas Lawrence, Kansas 66044. EUA.

(13). - Refere-se aos índios cherokee do sudeste dos Estados Unidos. Os cherokee tornaram-se o povo índio mais avançado, adaptando-se à civilizaçāo ocidental, criando um alfabeto, um sistema do govêrno representativo, etc. Mais tarde foram exilados para o atual Estado de Oklahoma. Quando era presidente, Jefferson fêz um acôrdo com o estado de Geórgia, permitindo a perda das terras tradicionais dos cherokee. Vide Grace Steele Woodward, The Cherokees (Norman Oklahoma, 1963), passim e 122 e 130. Gilmer acompanhou Correa na visita aos cherokee em 1815, e escreveu "Reflections on the Institutions of the Cherokee Indians from Observations made during a recent visit to that tribe: In a Letter from a gentleman of Virginia to Robert Walsh Jun. - June Ist, 1817', The Analectic Magazine, XII, (julho-dezembro de 1818) (Philadelphia, 1818), 36-56. No artigo Gilmer opunha-se à introdução de teares entre os cherokee (p. 53). Para a visita vide Davis, loc. cit., 102. 